\title{
Compartmentalization of Metabolites and Enzymatic Mediation in Nutritive Cells of Cecidomyiidae Galls on Piper Arboreum Aubl. (Piperaceae)
}

\author{
Gracielle Pereira Bragança ${ }^{1}$, Denis Coelho de Oliveira $^{2}$ \& Rosy Mary dos Santos Isaias ${ }^{1}$ \\ ${ }^{1}$ Universidade Federal de Minas Gerais, Instituto de Ciências Biológicas, Departamento de Botânica, Laboratório \\ de Anatomia Vegetal. Caixa postal 486.31270-901, Belo Horizonte, Minas Gerais, Brazil \\ ${ }^{2}$ Universidade Federal de Uberlândia, Instituto de Biologia, Laboratório de Anatomia e Desenvolvimento Vegetal. \\ Caixa postal 593, Uberlândia, Minas Gerais, Brazil \\ Correspondence: Rosy Mary dos Santos Isaias, Universidade Federal de Minas Gerais, Instituto de Ciências \\ Biológicas, Departamento de Botânica, Laboratório de Anatomia Vegetal. Caixa postal 486.31270-901, Belo \\ Horizonte, Minas Gerais, Brazil. E-mail: rosy@icb.ufmg.br
}

Received: August 21, 2016

Accepted: September 6, $2016 \quad$ Online Published: October 21, 2016

doi:10.5539/jps.v6n1p11

URL: http://dx.doi.org/10.5539/jps.v6n1p11

\begin{abstract}
Galling insects commonly change the chemical profile of their host plant tissues during gall induction and establishment. As a consequence, galls accumulate a wide range of metabolites in specialized cells, which may be organized in a nutritive tissue and in outer storage cells. The nutrients compartmentalized in nutritive cells may be directly assessed or metabolized via enzymatic mediation, while the gall outer cortex may accumulate secondary metabolites. These secondary metabolites may configure a specialized chemical barrier against the attack of natural enemies. Either the nutritive inner cells or the outer cortical cells, with their specific metabolic apparatus, should differentiate under the chemical constraints of each host plant-galling herbivore interaction. This premise is herein addressed by the investigation of the histochemical profile of the non-galled leaves and galls induced by Diptera: Cecidomyiidae on Piper arboreum. The spatial compartmentalization of the nutritive and defensive metabolites indicates the new functions assumed during the redifferentiation of the host plant cells. The enzymatic mediation of the primary metabolites by sucrose synthase and invertases favors the nutritive requirements of the galling Cecidomyiidae or the structural maintenance of the gall. The accumulation of secondary metabolites is restrict to the tissue layers not involved in nutrition, and may act in the chemical protection against predators or parasitoids. Current results systematically document metabolites compartmentalization, evidence the impairment of toxic compounds storage in cells surrounding the larval chamber, as well as, detect the redirection of nutritive substances to the site of the Cecidomyiidae feeding. The activity of sucrose synthase is restrict to the nutritive tissue in the galls on Piper arboreum, and reinforces previous detection of this enzyme mediation in carbohydrate metabolism in Cecidomyiidae galls.
\end{abstract}

Keywords: chemical profile, cecidomyiidae, galling insect diet, gall metabolism

\section{Introduction}

Galling insects alter the morphogenetical patterns of their host plant organs by inducing cell redifferentiation (sensu Lev-Yadun, 2003), division and growth (Oliveira \& Isaias, 2010a; Isaias, Oliveira, \& Carneiro, 2011; Isaias, Oliveira, Carneiro, \& Kraus, 2014; Magalhães, Oliveira, Suzuki, \& Isaias, 2014). The new morphogenetical patterns generate specialized cells and tissues at the gall site, whose chemical and functional features are distinct from those of the host organs (Oliveira, Carneiro, Magalhães, \& Isaias, 2011; Castro, Oliveira, Moreira, Lemos-Filho, \& Isaias, 2012). The gall metabolic requirements generate a sink of primary and secondary metabolites, which may compartmentalize in protective and/or nutritive tissues (Carneiro, Castro, \& Isaias, 2014). The carbohydrates drained to the gall developmental site are responsible for plant cell machinery support (Oliveira, Christiano, Soares, \& Isaias, 2006; Castro et al. 2012), and can also act as potential signaling molecules for cell division and growth (Koch, 2004; Wind, Smeenkens, \& Hanson, 2010; Isaias, Oliveira, Moreira, Soares, \& Carneiro, 2015). The signaling function in gall sites has also been attributed to reactive oxygen species (ROS) (Oliveira \& Isaias 2010a; Oliveira, Moreira, \& Isaias, 2014; Isaias et al., 2014). ROS 
accumulation demands phenolics scavenging (Isaias et al., 2015), which, in turn, influence IAA regulation (Bedetti, Modolo, \& Isaias, 2014).

Proteins, lipids, reducing sugars or starch accumulate in the inner layers of the gall, i. e., the nutritive tissue, and can provide resources for the nutrition of the galling insect (Price, Waring, \& Fernandes, 1986, 1987; Bronner, 1992). Nevertheless, in some systems, the availability of these metabolites to the galling insect or to the maintenance of cell metabolism depends on enzymatic activities (Bronner, 1992; Oliveira Magalhães, Carneiro, Alvim, \& Isaias, 2010; Oliveira \& Isaias, 2010b; Carneiro et al., 2014). The patterns of enzymatic activities depend on the feeding behavior of the galling insects (Bronner, 1992), and on the chemical profile of the host plants (Oliveira et al. 2010, 2014; Oliveira \& Isaias, 2010b).

The enzymatic mediation of carbohydrates metabolism has been documented just for four galling herbivore-host plant systems in the Neotropics (Oliveira et al., 2010, 2011; Oliveira \& Isaias, 2010b; Carneiro et al., 2014). These four systems involve gall inducing Cecidomyiidae and Psylloidea with their divergent peculiarities, and demonstrated the non-exclusiveness of the carbohydrates accumulation to Cecidomyiidae galls. Among the investigated carbohydrates, sucrose is synthesized in the cytosol from photosynthetically fixed carbon, starch reserves or lipid metabolism (Wind et al., 2010), and is transported via phloem to other plant parts. The main enzymes responsible for sucrose metabolism are sucrose synthase (SuSy) and invertases, which catalyse the conversion of sucrose into glucose and fructose (Koch, 2004). In general, SuSy activity is associated to sink tissues and starch accumulation, while invertases mediate cell respiration, tissue growth and development (Koch, 2004; Wind et al., 2010). In galls, the metabolism of these enzymes was also related to the formation of histochemical gradients and maintenance of the gall tissues in Aspidosperma australe (Oliveira \& Isaias, 2010b). The sites of the galling herbivore`s nutrition seems to be crucial for the redifferentiation of the nutritive cells, as documented for Nothotrioza cattleiani galls on Psidium cattleianum (Carneiro, Pacheco, \& Isaias, 2015).

Outside the nutritive cells, Cecidomyiidae galls usually have sclerenchymatic cells, forming a mechanical protective layer, and an outer parenchymatic cortex. These outer cell layers usually accumulate secondary metabolites, such as alkaloids, flavonoids, phenolics and tannins (Nyman \& Julkunen-Titto, 2000; Oliveira et al., 2006; Formiga, Soares, \& Isaias, 2011; Isaias et al., 2014), and can protect the galling herbivores against the attack of parasitoids and predators, and the gall structure against cecidophagous (Price, Waring, \& Fernandes, 1987).

Cell redifferentiation and metabolism in gall outer and inner tissue layers are herein revisited in a Cecidomyiidae - Piper arboreum system. We assume that primary and secondary metabolites accumulate in distinct tissue compartments, as expected, but some metabolic steps of this gall should be dependent on the host plant carbohydrates metabolism rather than on the Cecidomyiidae feeding mode. If this is true, some similarities between the compartmentalization and metabolism of Cecidomyiidae and Psylloidea galls should be found.

The intralaminar lenticular galls on $P$. arboreum have nutritive cells limiting the larval chamber, where carbohydrates should accumulate, as previously observed in other two Neotropical Cecidomyiidae galls (Oliveira et al., 2010, 2011). Similarly, the accumulation of cabohydrates in nutritive like cells has been documented in a Psyllloidea gall (Oliveira et al., 2011; Carneiro et al., 2014). Both gall inducers should not come into contact with non-palatable secondary metabolites, and therefore, enzymes mediation and a spatial compartmentalization of nutritive and defensive metabolites in gall developmental site are expected. Current analyses focus on the following questions: (I) does the accumulation of primary and secondary metabolites follow the expected compartmentalization? (II) Is there any disruption for metabolites accumulation in response to the galling stimuli of the Cecidomyiidae on P. arboreum? (III) Are there any similarities between the enzymatic mediation of Cecidomyiidae and Psylloidea galls? And (IV) should ROS signaling involve sugar mediation during gall development on the Cecidomyiidae intralaminar leaf galls on P. arboreum?

\section{Methods}

Samples of non galled leaves (NGL) and mature leaf galls (MG) induced by an unidentified species of Diptera: Cecidomyiidae on Piper arboreum were accompanied and collected from September 2013 to March 2014 at the ecological station of Universidade Federal de Minas Gerais in Belo Horizonte, Minas Gerais state, Brazil.

\subsection{Histochemical Assays}

Fresh samples $(n \geq 5)$ were free-hand sectioned and submitted to histochemical tests with the following reagents: saturated solution of sudan Red B in $70^{\circ} \mathrm{GL}$ ethanol during 5 min to detect lipids (Brundett, Kendrick, \& Peterson, 1991); Fehling's reagent (Solution "A" - 7.9\% copper sulfate, and solution "B" - 34.6\% sodium potassium tartrate and $1 \%$ sodium hydroxide) heated to pre-boiling temperature for detecting reducing sugars 
(Sass, 1951); Lugol's reagent (1\% potassium iodine-iodide solution) during 5 min for starch detection (Johansen, 1940); $0.1 \%$ bromophenol blue in a saturated solution of magnesium chloride in ethanol during 15 min, and later washed in acetic acid and water, for the detection of proteins (Baker, 1958); 1\% ferric chloride during 5 min, for phenolic compounds detection (Johansen, 1940); Dragendorff's reagent (Solution "A" - 12.5\% bismuth nitrate in $25 \%$ acetic acid, and solution "B" $40 \%$ potassium iodide) during $5 \mathrm{~min}$ for the detection of alkaloids (Johansen, 1940); Wiesner's reagent (2\% phloroglucinol in acidified solution) during $5 \mathrm{~min}$ for lignins detection (Johansen, 1940); fixation in $0.5 \%$ caffeine sodium benzoate in $90 \%$ butanol, followed by incubation in $1 \%$ p-dimethylaminocinnamaldehyde (DMACA) during $30 \mathrm{~min}$ for the detection of flavonoids (Feucht, Schmid, \& Christ, 1986); $1 \%$ a -naftol and 1\% dimethyl-p-phenylenediamine in phosphate buffer (pH 7.2) (NADI) during $30 \mathrm{~min}$ for the detection of terpenoids (David \& Carde, 1964), and Lieberman-Buchard's reagent (concentrated solution of sulfuric acid and acetic acid, 1:1, v/v) during $1 \mathrm{~min}$ for the detection of triterpenes (Wagner, Bladt, \& Zgainski, 1984). The sections were washed in water and photographed under an optical microscope (Zeiss Primo Star $^{\circledR}$ ) with a digital camera (Canon Power Shot A $630^{\circledR}$ ). Blank sections were used for the comparison of results.

\subsection{Enzymatic Activity}

For the detection of the activity of acid phosphatase, the sections were incubated in $0.012 \%$ lead nitrate and $0.1 \mathrm{M}$ potassium sodium glicerophosphate in $0.5 \mathrm{M}$ acetate buffer $(\mathrm{pH} 4.5)$ for 24 hours, at room temperature. The sections were washed in distilled water, and incubated in $1 \%$ ammonium sulfate for $5 \mathrm{~min}$. As a control, the samples were not submitted to potassium sodium glicerophosphate (Gomori, 1956). For the detection of phosphorylase activity, the sections were incubated for two hours in $1 \%$ glucose-1-phosphate in $0.1 \mathrm{M}$ acetate

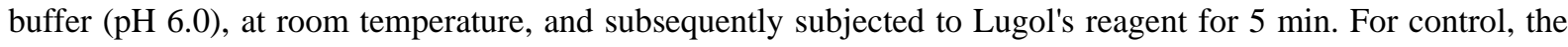
samples were not incubated in glucose-1-phosphate (Jensen, 1962). For observation of invertase activity, the sections were incubated for 3 hours at room temperature in a solution containing $0.024 \%$ tetrazolium blue (NBT), $0.014 \%$ phenazin methosulfate, $30 \mathrm{U}$ of glucose oxidase and $30 \mathrm{mM}$ of sucrose, $0.38 \mathrm{mM}$ sodium phosphate buffer ( $\mathrm{pH}$ 7.5). The control was subjected to the reaction media without sucrose (Zrenner, Salanoubat, Willmitzer, \& Sonnewald, 1995; Doehlert \& Felker 1987). For detection of sucrose synthase activity, the sections were fixed in $2 \%$ paraformaldehyde with $2 \%$ polyvinylpyrrolidone and $0.005 \mathrm{M}$ of dithiothreitol (pH 7.0) for 1 hour at $4^{\circ} \mathrm{C}$. Later, they were incubated in a solution containing $5 \mu \mathrm{L}$ of $150 \mathrm{mM} \mathrm{NADH}, 5 \mu \mathrm{l}(1 \mathrm{U})$ of phosphoglucomutase, $5 \mu \mathrm{l}$ of $3 \mathrm{mM}$ glucose 1,6-bisphosphate, $5 \mu \mathrm{l}(1 \mathrm{U})$ of glucose-6-phosphate dehydrogenase, $5 \mu \mathrm{l}(1 \mathrm{U})$ of UDPG pyrophosphorylase, $280 \mu \mathrm{L}$ of $0.07 \%$ aqueous solution of blue tetrazolium (NTB), $350 \mu 1$ of buffer and $50 \mu \mathrm{L}$ substrate during 30 minutes. The buffer contained $10 \mathrm{mM} \mathrm{MgCl} 2,2 \mathrm{mM}$ EDTA, $100 \mathrm{mM}$ HEPES, $0.2 \%$ BSA and 2mM EGTA (pH 7.4). The substrate consisted of $15 \mathrm{mM}$ UDP, $0.75 \mathrm{mM}$ sucrose, $15 \mathrm{mM}$ pyrophosphate. Two controls were used. In the first control, the glucose 1,6-bisphosphate and pyrophosphate were not added, and for the second control, the sucrose was suppressed (Wittich \& Vreugdenhil 1998).

\subsection{Histochemical Test for Reactive Oxygen Species (ROS)}

ROS were detected by immersion of the sections in $0.5 \%$ 3.3'-diaminobenzidine (DAB) during 15 - 60min, in the dark (Rossetti \& Bonatti 2001). The sections were washed in water and photographed under an optical microscope (Zeiss Primo Star ${ }^{\circledR}$ ) with a digital camera (Canon Power Shot A $630^{\circledR}$ ). Blank sections were used for the comparison of results.

\section{Results}

\subsection{General Features}

Leaf galls on Piper arboreum are intralaminar and lenticular. They project to both leaf surfaces, and has a uniseriate epidermis, an outer parenchymatic cortex, an inner cortex composed of sclerenchymatic cells, and a nutritive zone involving the larval chamber, which houses the galling Cecidomyiidae (Figure 1 A-C). 


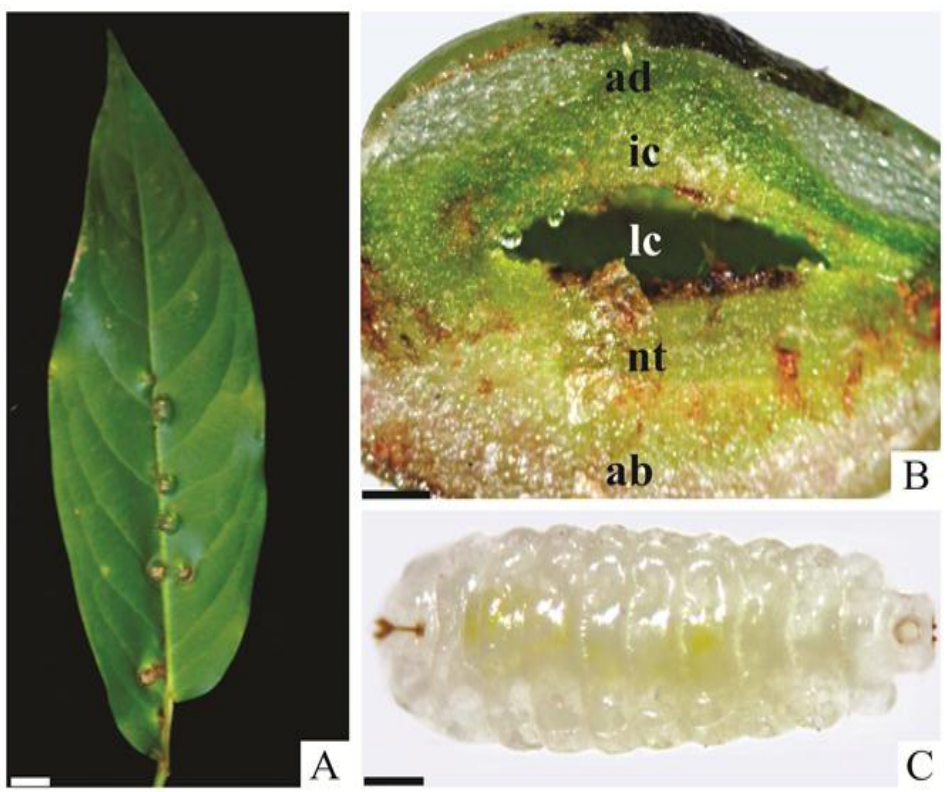

Figure 1. Leaf galls on Piper arboreum Aubl (Piperaceae)

A: Leaf with galls viewed by the adaxial surface. B: Hemisection of a mature gall evidencing the adaxial outer cortex, abaxial outer cortex, inner cortex, larval chamber, and nutritive tissue. C: Cecidomyiidae larva. ab, abaxial outer cortex; ad, adaxial outer cortex ic, inner cortex; lc, larval chamber; nt, nutritive tissue. Scale bars = 1cm (A), $0.5 \mathrm{~mm}(\mathrm{~B}), 2 \mathrm{~mm}(\mathrm{C})$.

Table 1. Histochemical detection of metabolites and enzymes in non-galled leaves of Piper arboreum Aubl (Piperaceae)

\begin{tabular}{llllllll}
\hline \multirow{2}{*}{ Metabolites } & \multicolumn{7}{l}{ Tissues of non-galled leaves } \\
\cline { 2 - 7 } & ADEP & ADHP & PP & SP & VB & ABHP & ABEP \\
\hline Phenolic compounds & - & + & - & - & - & + & - \\
Flavonoids & - & + & - & - & - & + & - \\
Alkaloids & - & + & - & - & - & + & - \\
Triterpenes & - & + & - & - & - & + & - \\
Lignins & - & - & - & - & + & - & - \\
Lipids & - & - & - & - & - & + & - \\
Reducing sugar & - & + & - & - & - & + & - \\
Starch & - & - & + & + & - & - & - \\
Proteins & - & - & + & + & - & - & - \\
Invertase & - & + & - & - & - & + & - \\
Sucrose Sintase & - & - & - & - & + & - & - \\
Acid phosphatase & - & - & - & - & - & - & - \\
Phosphorylase & - & - & - & - & - & - & - \\
Reactive oxygen species & + & + & + & + & + & + & + \\
\hline
\end{tabular}

Note. $\mathrm{ABEP}=$ abaxial epidermis; $\mathrm{ABHP}=$ abaxial hypodermis; $\mathrm{ADEP}=$ adaxial epidermis; $\mathrm{ADHP}=$ adaxial hypodermis; $\mathrm{PP}$ $=$ palisade parenchyma; $\mathrm{SP}=$ spongy parenchyma; $\mathrm{VB}=$ vascular bundles. $(+)$ positive reaction, $(-)$ negative reaction . 


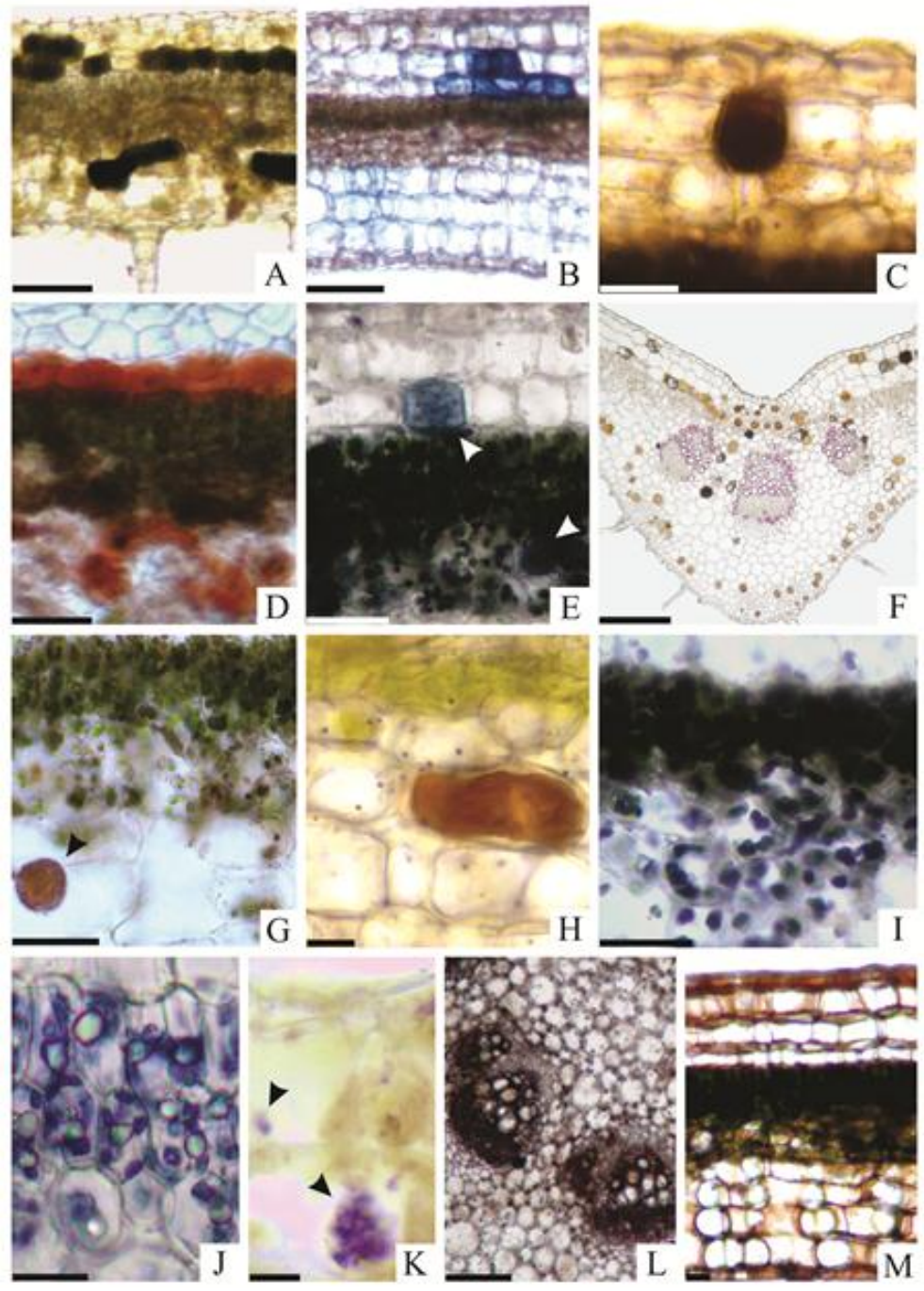

Figure 2. Histochemical tests in non-galled leaves of Piper arboreum Aubl (Piperaceae)

A: Reaction with ferric chloride evidencing the presence of phenolics in the hypodermis. B: DMACA revealing flavonoids in adaxial hypodermis. C: Alkaloids in the adaxial hypodermis. D: Reaction with Lieberman-Buchard's reagent showing triterpenes in the adaxial and abaxial hypodermis. E: NADI detecting terpenoids in adaxial hypodermis and idioblasts between the palisade and spongy parenchyma. F: Lignins in the cell walls of the xylem and pericyclic fibers. G: Sudan red demonstrating lipid droplets (arrows) in the abaxial hypodermis. H: Reducing sugars detected by Fehling`s reagent in the abaxial outer cortex. I: Lugol's reagent detecting starch in the palisade parenchyma and spongy parenchyma. J: Bromophenol blue indicating total proteins in the palisade parenchyma and spongy parenchyma. K: Activity of invertases in the adaxial hypodermis (arrow). L: Activity of sucrose synthase in the vascular bundles. M: Accumulation of ROS in the outer and inner gall cortices. Scale bars $=200 \mu \mathrm{m}(\mathrm{A}-\mathrm{D}, \mathrm{L}), 50 \mu \mathrm{m}(\mathrm{E}-\mathrm{I}, \mathrm{K}, \mathrm{M}), 30 \mu \mathrm{m}(\mathrm{J})$.

\subsection{Histochemical Profile of Non-Galled Leaves (NGL).}

Phenolic compounds, flavonoids, alkaloids, and triterpenes were detected in the cells of hypodermis in black, dark blue, brown and red, respectively (Figure 2A-D, Table 1). Terpenoids were detected in blue in the cells of the hypodermis, and also in the idioblasts located between the palisade and spongy parenchymas (Figure 2E, Table 1). Lignins were evidenced in red in the cell walls of the xylem and of the pericyclic fibers (Figure $2 \mathrm{~F}$, Table 1). Lipids were detected as red droplets in the cells of the abaxial hypodermis, while reducing sugars, forming red precipitates, were observed in the adaxial and abaxial hypodermis (Figure 2G-H, Table 1). Starch grains and proteins were detected as dark blue grains or precipitates in the palisade and spongy parenchyma (Figure 2I-J, Table 1). The activity of invertases was evidenced as a dark blue precipitate in the hypoderm and parenchyma cells of the veins (Figure 2K, Table 1). The activity of sucrose synthase (SuSy) was detected as a 
purple precipitate in the vascular bundles (Figure2L, Table 1). The activity of phosphorylase and acid phosphatase was not observed. The ROS were detected in the epidermis and chlorophyllous parenchyma of the NGL (Figure 2M, Table 1).

\subsection{Metabolites Compartmentalization in Cecidomyiidae Induced Galls on Piper Arboreum}

The outer cortical cells of the mature galls (MG) developed from the hypodermis of the NGL, and accumulated phenolic compounds, flavonoids, alkaloids and terpenoids (Figure 3A-C, Table 2). Terpenoids occurred in idioblasts located between the palisade and spongy parenchyma of NGL, but they were not observed in the gall inner cortex (Figure3D, Table 2). Triterpenes were not evidenced in MG (Table 2). Lignins were detected in the cell walls of the xylem and of the pericyclic fibers both in NGL and MG. In MG, lignins were also observed in the cell walls of the sclerenchyma surrounding the nutritive tissue (Figure 3E, Table 2). Lipids were observed in the outer region, and also in the nutritive tissue of the MG (Figure 3F, Table 2). Reducing sugars were revealed in the cells of the adaxial and abaxial outer cortices (Figure 3G, Table 2). The detection of starch was more intense in the cells of the inner cortex and next to the larval chamber, increasing laterally towards the non-galled region. Starch was also detected in the lignified-walled cells (Figure 3H, Table 2). Proteins were detected in the nutritive tissue (Figure 3I, Table 2).

\subsection{Enzymatic Activity}

The activity of invertases was detected in the cells adjacent to the larval chamber, and formed a centrifugal gradient towards the non-galled region (Figure 3J, Table 2). The activity of SuSy was detected homogeneously throughout the nutritive tissue and vascular bundles (Figure 3K, Table 2). The activity of phosphorylase and acid phosphatase was not observed either in NGL or MG.

3.5 ROS Detection. In MG, the ROS accumulated in a centrifugal gradient, decreasing towards the outer cortical tissue layers (Figure 3L, Table 2).

Table 2. Histochemical detection of metabolites and enzymes in Cecidomyiidae galls on Piper arboreum Aubl (Piperaceae)

\begin{tabular}{llllllll}
\hline \multirow{2}{*}{ Metabolites } & \multicolumn{7}{c}{ Tissues of mature galls } \\
\cline { 2 - 7 } & ADEP & AD & IC & NT & VB & AB & ABEP \\
\hline Phenolic compounds & - & + & - & - & - & + & - \\
Flavonoids & - & + & - & - & - & + & - \\
Alkaloids & - & + & - & - & - & + & - \\
Triterpenes & - & - & - & - & - & - & - \\
Lignins & - & - & + & - & + & - & - \\
Lipids & - & + & - & + & - & + & - \\
Reducing sugar & - & + & - & - & - & + & - \\
Starch & - & - & + & + & - & - & - \\
Proteins & - & - & - & + & - & - & - \\
Invertase & - & - & - & + & - & - & - \\
Sucrose Sintase & - & - & - & + & + & - & - \\
Acid phosphatase & - & - & - & - & - & - & - \\
Phosphorylase & - & - & - & - & - & - & - \\
Reactive oxygen species & + & + & + & + & + & + & + \\
\hline
\end{tabular}

Note. $\mathrm{AB}=$ abaxial outer cortex $; \mathrm{AD}=$ adaxial outer cortex; $\mathrm{ABEP}=$ abaxial epidermis; $\mathrm{ADEP}=$ adaxial epidemis; IC = inner cortex; NT = nutritive tissue; VB = vascular bundles. (+) positive reaction, (-) negative reaction. 


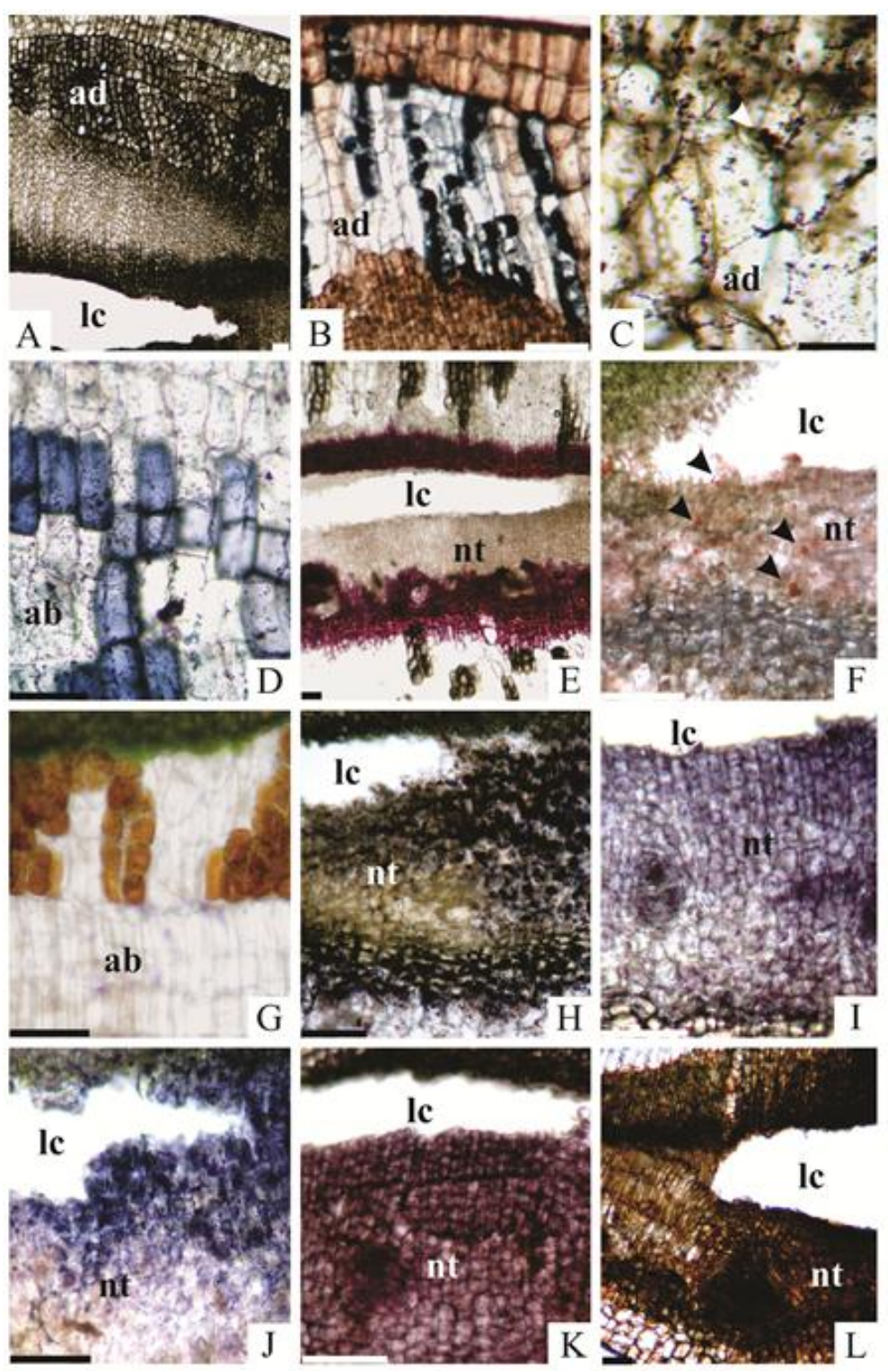

Figure 3. Histochemical tests in Cecidomyiidae galls on Piper arboreum Aubl (Piperaceae)

A: Ferric chloride evidencing phenolics in the outer cortex. B: DMACA revealing flavonoids in the outer cortex. C: Alkaloids detected by Draggendorff's reagent in the outer cortex (arrow). D: NADI detecting terpenoids in the outer cortex. E: Lignins in cell walls of the sclerenchymatic sheath. F: Sudan red demonstrating lipid droplets (arrows) in the nutritive tissue. G: Reducing sugars evidenced by Fehling`s reagent in the abaxial outer cortex. H: Lugol's reagent detecting starch in the nutritive tissue and lignified cells. I: Bromophenol blue indicating total proteins in the nutritive tissue. J: Activity of invertases in the nutritive tissue. K: Activity of sucrose synthase in the nutritive tissue. L: Accumulation of ROS in the outer and inner cortices of the gall. ab, abaxial outer cortex; ad, adaxial outer cortex; ic, inner cortex; lc, larval chamber; nt, nutritive tissue. Scale bars $=200 \mu \mathrm{m}(\mathrm{A}-\mathrm{L}), 50 \mu \mathrm{m}(\mathrm{F})$.

\section{Discussion}

\subsection{Compartimentalization of Metabolites}

Two distinct compartments with accumulation of primary and secondary metabolites were observed in the leaf galls on P. arboreum. Primary metabolites have been especially detected in the inner tissues, while secondary metabolites accumulated only in the outer cortical parenchyma, which corroborates the expected spatial functional division of gall tissues. The outer cells were converted from photosynthetic and respiratory compartments towards defensive tissues, while the inner cells assumed a specialized nutritional role in 
redifferentiated gall tissues.

The defensive compartment, i.e. the outer cortex of $P$. arboreum leaf gall, accumulated alkaloids, terpenes, and phenolics, which have been considered waste products of plant metabolism (Roberts \& Wink, 1998). Nevertheless, they have been contemporarily evaluated as sources of nitrogen or energetic lipids, and ROS scavenging molecules (Isaias et al., 2015), all of them necessary for the maintenance both of the host plant and gall metabolism. In spite of their involvement in antioxidant mechanisms (Blokhina, Virolainen, \& Fagerstedt, 2003; Detoni, Vasconcelos, Rust, Isaias, \& Soares, 2011), alkaloids, terpenes, and phenolics may secondarily deter or discourage the attack of predators, due to their toxicity ( Rhodes, 1994; Róstas, Maag, Ikegami, \& Inbar, 2013). In galls, because of the high oxidative stress, the role of phenolics and flavonoid derivatives has been discussed as ROS dissipation, an efficient strategy to recover the redox-potential homeostasis (Isaias et al., 2015). Also, the phenolics are involved in IAA metabolism and consequently influence cell hypertrophy at gall site (Bedetti et al., 2014).

Even though the terpenes accumulated all over leaf mesophyll, they are detected exclusively in the outer compartment of the galls on $P$. arboreum, reinforcing the chemical protectiveness of the gall outer tissue layers. The impairment of the terpenic idioblasts differentiation in the nutritive tissue of the galls on $P$. arboreum should have favored the gall inducer, which did not come into contact with the toxic potential of the terpenes, and their anti-herbivore properties (Gershenzon, 1994). The strategy of disrupting the differentitation of terpenic idioblasts have been previously observed in the galling herbivores-Lantana camara systems (Moura, Isaias, \& Soares, 2005; Moura, Isaias, \& Soares, 2008).

\subsection{Double Metabolites Accumulation in the Inner Compartment}

As a host plant potentiality, lipid droplets were detected in the cells of the cortical parenchyma, originated from the NGL mesophyll, their intrinsic location. The lipids accumulated in the inner tissue layers may function as an energetic resource both for the galling Cecidomyiidae's nutrition and gall development. Even though attributed to Cynipidae (Bronner, 1992) and Lepidoptera galls (Vecchi, Menezes, Oliveira, Ferreira, \& Isaias, 2013), lipidic droplets have been previously detected in some Cecidomyiidae galls of Aspidosperma spruceanum (Oliveira et al., 2010), Copaifera langsdorffii (Oliveira et al., 2011), and Marcetia taxifolia (Ferreira \& Isaias, 2014). The accumulation of lipids in such galls has been related to the potential of the host plants for such accumulation (Oliveira et al., 2011; Ferreira \& Isaias, 2014), as is true for P. arboreum.

The inner compartment of the galls on $P$. arboreum, i.e., the nutritive tissue, also accumulates proteins, similarly to the Cecidomyiidae galls on Aspidosperma spruceanum (Oliveira et al., 2010). Proteins are excellent nutritive resources for the galling herbivores, and may have accumulated as a cellular response to the increased oxidative and respiratory stresses established during the cecidogenetic process (Schönrogge, Harper, Lichtenstein, 2000). The increased level of proteins is followed by high levels of hexoses (Sturm \& Tang, 1999), which are products of the activity of sucrose synthase and invertases (Roitsch \& Gonzalez, 2004). The detection of invertases indicates the fast convertion of sucrose, and the activation of a mechanism of plant defense by increasing the synthesis of secondary metabolites (Wind et al., 2010; Sturm \& Tang 1999). The double accumulation of nutritive compounds, such as lipids and proteins, in the nutritive tissue of a Cecidomyiidae gall is not the expected pattern, which should be carbohydrates storage (Bronner, 1992; Oliveira et al., 2010; Oliveira et al., 2011). This double stimuli is therefore a novelty for Cecidomyiidae galls in the Neotropics, and indicates a surplus for the galling herbivore nutrition.

\subsection{Enzymatic Mediation of Carbohydrates Accumulation}

The activity of sucrose synthase (SuSy) and invertases detected in the nutritive tissue of the galls on P. arboreum corroborated the metabolic similarity between Psylloidea and Cecidomyiidae galls. Both enzymes have been previously detected in galls induced by Pseudophacopteron aspidospermii (Malenovsky, Burckhardt, Queiroz, Isaias, \& Oliveira, 2015) on Aspidosperma australe (Oliveira et al., 2010) and by a Cecidomyiidae on A. spruceanum (Oliveira \& Isaias, 2010b). This enzymatic detection indicates a host plant metabolic requirement or potential rather than a dependence on the galling herbivore mode of feeding.

Moreover, current results demonstrate a common site for the activity of SuSy in the Cecidomyiidae galls on $P$. arboreum, and on A. spruceanum and Copaifera langsdorffii, which diverges in the $P$. aspidospermii galls on A. australe, where the activity of SuSy was restricted to the vascular bundles. Based on such comparison, we can conclude that the feeding sites of the galling herbivores does not determine the host plant cells metabolism, but may determine the sites of enzymes activity. The activity of SuSy is commonly responsible for the reversible cleavage of sucrose into fructose and UDP-glucose (Amor, Haigler, Johnson, Wainscott, \& Delmer, 1995; Koch, 2004), but may be especially related to the synthesis of starch observed in the nutritive tissue of the galls on $P$. 
arboreum. Furthermore, this enzyme provides substrate (UDP-glucose) for the formation of cell wall polysaccharides (Nolte \& Koch, 1993; Salnikov, Grimson, Seagull, \& Haigler, 2003), whose dynamics, together with the carbohydrates metabolism, have crucial roles in the development of the gall structure (Formiga et al., 2013, Oliveira et al., 2014, Carneiro et al., 2015), and consequently in the survival of the galling herbivore.

In terms of cell metabolism, the gall on $P$. arboreum functions as a new organ, in a strict intralaminar continuum with its host tissues, establishing a sink of photoassimilates, which culminate in the accumulation of metabolites involved in its own development, and in the feeding activity of its associated galling herbivore (Rehill \& Schultz, 2003; Castro et al., 2012). The nutrients can be redirected and compartmentalized into the nutritive tissue by two pathways. The first one is the transport of sucrose, via phloem, from the non-galled portions of the host leaf towards the gall site, where it is promptly metabolized and converted into starch. The conversion of sugars into starch occurs in a SuSy dependent via, which produces UDP-glucose as demonstrated for tubers of potato (Baroja-Fernández et al., 2009). In the second pathway, the sucrose is irreversibly cleaved by the activity of invertases into glucose and fructose, which are used in cell respiration (Koch, 2004). The invertases are, indeed, the major sucrose-degrading enzyme in plants, as demonstrated in Arabidopsis, where their low levels affect plant growth (Barrat et al., 2009). In insect galls, the force of the sink towards the nutritive tissues seems to be maintained by the high cytological metabolism and the dynamics between the activity of SuSy and invertases (Oliveira et al., 2010), as can be inferred for $P$. arboreum galls.

\subsection{ROS Accumulation and Reducing Sugars Suppression in Nutritive Cells}

Due to the high activity of SuSy and invertases in the nutritive tissue, as well as the direct involvement of sugars in insect feeding, a gradient of carbohydrates should be expected (Bronner, 1992; Oliveira et al., 2014). However, the accumulation of reducing sugars is impaired in the nutritive tissue of the galls on P. arboreum, indicating that the sucrose is promptly metabolized to starch synthesis and monosaccharides used in cell respiration and gall growth. This supposed increase of cell respiration is corroborated by the accumulation of ROS in the nutritive tissue of the MG on $P$. arboreum. The relationship between the absence of reducing sugars and high accumulation of ROS in the inner tissues is theoretically proposed for Cecidomyiidae-induced galls. High levels of sugars are expected for Cecidomyiidae galls (Bronner, 1992), and should be crucial for disrupting the high oxidative stress detected by the presence of $\mathrm{H}_{2} \mathrm{O}_{2}$ in the inner compartment, as hypothesized by Isaias et al. (2015).

\section{Conclusion}

The galling Cecidomyiidae promotes the compartmentalization of specific secondary and primary metabolites of its host leaves, guaranteeing benefits to its own survivorship. The outer compartmentalization of the secondary metabolites maintained the pattern of the original host tissues of $P$. arboreum leaves, and may confer protection against natural enemies. The inner compartmentalization of primary metabolites mediated by enzymes reflects two important metabolic steps of gall development: (1) the sink of photoassimilates and the storage of starch mediated by SuSy activity, and (2) the accumulation of proteins and lipids in nutritive tissues, as well as a high respiratory metabolism mediated by invertases activity. The conversion of sucrose into monossacharides is a common metabolic step shared by the Cecidomyiidae and the Psylloidea galls. However such conversion occurs in distinct sites of enzymes activity, which is imposed by the different feeding habits of the two taxa of galling herbivores, and their target cells.

The intralaminar galls on $P$. arboreum have two functional inversions regarding the compartmentalization of metabolites. The outer compartment accumulates reducing sugars, expected to occur in the nutritive cells, and terpenoids, whose synthesis is disrupted in the inner gall tissues. We theoretically propose that a consequence of these new sites of accumulation is a deviation of functions, with reducing sugars taking part in cell respiration in the outer tissue layers, and mediating ROS metabolism all over gall cortex. The terpenoids, whose presence in the nutritive cells should intoxicate the galling larvae, and consequently impair gall development, may contribute to gall chemical defense against natural enemies in the outer cortical cells.

\section{Acknowledgments}

The authors thank Coordenação de Aperfeiçoamento de Pessoal de Nível Superior (CAPES), Conselho Nacional de Desenvolvimento Científico e Tecnológico (CNPq), and Fundação de Apoio à Pesquisa de Minas Gerais (FAPEMIG) for financial support.

\section{References}

Amor, Y., Haigler, C. H., Johnson, S., Wainscott, M., \& Delmer, D. P. (1995). A Membrane-associated form of Sucrose Synthase and its Potential role in Synthesis of Cellulose and Callose in Plants. Proceedings of the 
National Academy of Sciences, 92(20), 9353-9357. http://dx.doi.org/10.1073/pnas.92.20.9353

Baker, J. R. (1958). Note on the use of Bromophenol Blue for the Histochemical Recognition of Protein. Quarterly Journal of Microscopical Science, 99, 459-460.

Baroja-Fernández, E., Muñoz, F. J., Montero, M., Etxeberria, E., Sesma, M.T., ... Pozueta-Romero, J. (2009). Enhancing Sucrose Synthase activity in Transgenic Potato (Solanum tuberosum L) Tubers results in increased levels of Starch, ADPglucose and UDPglucose and total yield. Plant Cell Physiology, 50(9), 1651-1662. http://dx.doi.org/10.1093/pcp/pcp108

Barrat, D. H. P., Derbyshire, P., Findlay, K., Pike, M., Wellner, N., ... Smith, A. M. (2009). Normal Growth of Arabidopsis Requires Cytosolic Invertase but not Sucrose Synthase. Proceedings of the National Academy of Sciences, 106(31), 13124 -13129. http://dx.doi.org/10.1073/pnas.0900689106

Bedetti, C. S., Modolo, L.V., \& Isaias, R. M. S (2014). The Role of Phenolics in the Control of Auxin in galls of Piptadenia gonoacantha (Mart) MacBr (Fabaceae: Mimosoideae). Biochemical Systematics and Ecology, 55, 53-59. http://dx.doi.org/10.1016/j.bse.2014.02.016

Blokhina, O., Virolainen, E., \& Fagerstedt, K. V. (2003). Antioxidants, Oxidative damage and Oxygen Deprivation Stress: a Review. Annals of Botany, 91, 179-194. http://dx.doi.org/10.1093/aob/mcf118

Bronner, R. (1992). The role of nutritive cells in the nutrition of cynipids and cecidomyiids. In J. D Shorthouse \& O. Rohfritsch, (Eds.), Biology of insect-induced galls (pp. 118-140). Oxford University Press, Oxford.

Brundett, M. C., Kendrick, B., \& Peterson, C. A. (1991). Efficient Lipid Staining in Plant Material with Sudan Red 7B or Fluorol Yellow 088 in Polyethylene Glycol-glycerol. Biotechnic \& Histochemistry, 66(3), 111-116. http://dx.doi.org/10.3109/10520299109110562

Carneiro, R. G. S., Castro, A. C., \& Isaias, R. M. S. (2014). Unique Histochemical Gradients in Photosynthesis-deficient Plant Gall. South African Journal of Botany, 92, 94-104. http://dx.doi.org/10.1016/j.sajb.2014.02.011

Carneiro, R. G. S., Pacheco, P., \& Isaias, R. M. S. (2015). Could the Extended Phenotype Extend to the Cellular and Subcellular Levels in Insect-induced Galls? PLoS One, http://dx.doi.org/101371/ journalpone012933.

Castro, A. C., Oliveira, D. C., Moreira, A. S. F. P., Lemos-Filho, J. P., \& Isaias, R. M. S. (2012). Source-Sink Relationship and Photosynthesis in the Horn-shaped Gall and its Host Plant Copaifera langsdorffii Desf (Fabaceae). South African Journal of Botany, 83, 121-126. http://dx.doi.org/10.1016/j.sajb.2012.08.007

David, R. \& Carde, J. (1964). Coloration différentielle des inclusions lipidiques et terpeniques des pseudophylles du Pin maritime au moyen du réactif Nadi. Comptes rendus hebdomadaires des séances de l'Académie des sciences, 258, 1338-1340.

Detoni, M. L., Vasconcelos, E. G., Rust, N. M., Isaias, R. M. S., \& Soares, G. L. G. (2011). Seasonal Variation of Phenolic Content in Galled and Non-galled Tissues of Calliandra brevipes Benth (Fabaceae: Mimosoidae). Acta Botanica Brasilica, 25(3), 601-604. http://dx.doi.org/10.1590/S0102-33062011000300013

Doehlert, D. C. \& Felker, F. C. (1987). Characterization and Distribution of Invertase Activity in Developing Maize (Zea mays) Kernels. Physiology Plantarum, 70, 51-57. http://dx.doi.org/10.1111/j.1399-3054.1987.tb08695.x

Ferreira, B. G. \& Isaias, R. M. S. (2014). Floral-like Destiny Induced by a Galling Cecidomyiidae on the Axillary Buds of Marcetia taxifolia (Melastomataceae). Flora, 209, 391-400. http://dx.doi.org/10.1016/j.flora.2014.06.004

Feucht, W., Schmid, P. P. S., Christ, E. (1986). Distribution of Flavonols in Meristematic and Mature Tissues of Prunus avium Shoots. Journal of Plant Physiology, 125, 1-8. http://dx.doi.org/10.1016/S0176-1617(86)80237-1

Formiga, A. T., Oliveira, D. C., Ferreira, B. G., Magalhães, T. A., Castro, A. C., ... Isaias, R. M. S. (2013). The Role of Pectic composition of Cell Walls in the Determination of the New Shape-functional Design in Galls of Baccharis reticularia (Asteraceae). Protoplasma, 250, 899-908. http://dx.doi.org/10.1007/s00709-012-0473-8

Formiga, A. T., Soares, G. L. G., \& Isaias, R. M. S. (2011). Responses of the Host Plant Tissues to Gall Induction in Aspidosperma spruceanum Müell Arg (Apocynaceae). American Journal of plant Science, 2, 823-834. http://dx.doi.org/10.4236/ajps.2011.26097 
Gershenzon, J. (1994). Metabolic Costs of Terpenoid Accumulation in Higher Plants. Journal of Chemical Ecology, 20(6)1281-1328. http://dx.doi.org/10.1007/BF02059810.

Gomori, G. (1956). Histochemical Methods for Acid Phosphatase. Journal of Histochemistry and Cytochemistry, 4(5), 453-461. http://dx.doi.org/10.1177/4.5.453

Isaias, R. M. S, Oliveira, D. C. \& Carneiro, R. G. S (2011). Role of Euphalerus ostreoides (Hemiptera: Psylloidea) in Manipulating Leaflet Ontogenesis of Lonchocarpus muehlbergianus (Fabaceae). Botany, 89, 581-592. http://dx.doi.org/10.1139/cjb-2013-0125

Isaias, R. M. S, Oliveira, D. C., Carneiro, R. G. S., \& Kraus, J. E. (2014). Developmental anatomy of galls in the neotropics, arthropods stimuli versus host plant constraints. In G.W., Fernandes \& J.C. Santos, (Eds.), Neotropical Insect Galls (pp. 15-34). Springer Netherlands.

Isaias, R. M. S., Oliveira, D. C., Moreira, A. S. F. P., Soares, G. L. G., \& Carneiro, R. G. S. (2015). The Imbalance of Redox Homeostasis in Arthropod-induced Plant Galls: Mechanisms of Stress Generation and Dissipation. Biochimica et Biophysica Acta, 1850, 1509-1517. http://dx.doi.org/10.1016/j.bbagen.2015.03.007.

Jensen, W. A. (1962). Botanical histochemistry. WH Freeman, San Francisco.

Johansen, D. A. (1940). Plant microtechnique. McGraw-Hill, New York.

Koch, K. (2004). Sucrose Metabolism: Regulatory Mechanisms and Pivotal Roles in Sugar Sensing and Plant Development. Current Opinion in Plant Biology, 7(3), 235-246. http://dx.doi.org/10.1016/j.pbi.2004.03.014

Lev-Yadun, S. (2003). Stem Cells in Plants are Differentiated Too. Current Topics in Plant Biology, 4, 93-102.

Magalhães, T. A., Oliveira, D. C., Suzuki, A. Y. M., \& Isaias, R. M. S. (2014). Patterns of Cell Elongation in the Determination of the Final Shape of Baccharopelma dracunculifoliae (Psyllidae) on Baccharis dracunculifolia DC (Asteraceae). Protoplasma, 251, 747-753. http://dx.doi.org/10.1007/s00709-013-0574-z

Malenovsky, I., Burckhardt, D., Queiroz, D. L., Isaias, R. M. S., \& Oliveira, D. C. (2015). Descriptions of Two New Pseudophacopteron species (Hemiptera: Psylloidea: Phacopteronidae) inducing galls on Aspidosperma (Apocynaceae) in Brazil. Acta Entomologica Musei Nationalis Pragae, 55(2), 513-538.

Moura, M. Z. D., Isaias, R. M. S., \& Soares, G. L. G. (2005). Ontogenesis of Internal Secretory Cells in Leaves of Lantana camara (Verbenaceae). Botanical Journal of the Linnean Society, 148(4), 427-431. http://dx.doi.org/10.1111/j.1095-8339.2005.00426.x

Moura, M. Z. D., Isaias, R. M. S., \& Soares, G. L. G. (2008). Species-specific Changes in Tissue Morphogenesis Induced by two Arthropod Leaf Gallers in Lantana camara (Verbenaceae). Australian Journal of Botany, 56(2), 153-160. http://dx.doi.org/10.1071/BT07131

Nolte, D. K., \& Koch, E. K. (1993). Companion-Cell Specific Localization of Sucrose Synthase in Zones of Phloem Loading and Unloading. Plant Physiology, 101(3), 899-905.

Nyman, T., \& Julkunen-Titto, R. (2000). Manipulation of the Phenolic Chemistry of Willows by Gall-inducing Sawflies. Proceedings of the national academy of Sciences, 97, 13184-13187. http://dx.doi.org/10.1073/pnas.230294097

Oliveira, D. C., \& Isaias, R. M. S (2010b). Cytological and Histochemical Gradients Induced by a Sucking Insect in Galls of Aspidosperma australe Arg Muell (Apocynaceae). Plant Science, 178, 350-358. http://dx.doi.org/10.1016/j.plantsci.2010.02.002

Oliveira, D. C., \& Isaias, R. M. S. (2010a). Redifferentiation of Leaflet Tissues During Midrib Gall Development in Copaifera langsdorffii (Fabaceae). South African Journal of Botany, 76, 239-248. http://dx.doi.org/10.1016/j.sajb.2009.10.011

Oliveira, D. C., Carneiro, R. G. S., Magalhães, T. A., \& Isaias, R. M. S. (2011). Cytological and Histochemical Gradients on Two Copaifera langsdorffii Desf (Fabaceae) Cecidomyiidae Gall Systems. Protoplasma, 248(4), 829-837. http://dx.doi.org/10.1007/s00709-010-0258-x

Oliveira, D. C., Christiano, J. C. S., Soares, G. L. G., \& Isaias, R. M. S. (2006). Reações de Defesas Químicas e Estruturais de Lonchocarpus muehlbergianus Hassl (Fabaceae) à Ação do Galhador Euphalerus ostreoides Crawf (Hemiptera: Psyllidae). Revista Brasileira de Botânica, 29, 657-667. http://dx.doi.org/10.1590/S0100-84042006000400015

Oliveira, D. C., Magalhães, T. A., Carneiro, R. G. S., Alvim, M. N., \& Isaias, R. M. S. (2010). Do Cecidomyiidae 
Galls of Aspidosperma spruceanum (Apocynaceae) Fit the Pre-established Cytological and Histochemical Patterns? Protoplasma, 242, 81-93. http://dx.doi.org/10.1007/s00709-010-0128-6

Oliveira, D. C., Moreira, A. S. F. P., \& Isaias, R. M. S. (2014). Functional gradients in insect gall tissues, studies on neotropical host plants. In G.W., Fernandes \& J.C. Santos, (Eds.), Neotropical Insect Galls (pp. 35-49). Springer Netherlands. http://dx.doi.org/10.1007/978-94-017-8783-3_3

Price, P. W., Waring, G. L., \& Fernandes, G. W. (1986). Hypotheses on the Adaptive Nature of Galls. Proceedings of the Entomological Society of Washington, 88, 361-363.

Price, P. W., Waring, G. L., \& Fernandes, G. W. (1987). Adaptive Nature of Insect Galls. Environmental Entomology, 16, 15-24. http://dx.doi.org/10.1093/ee/16.1.15

Rehill. B. J., \& Schultz, J. C. (2003). Enhanced Invertase Activities in the Galls of Hormaphis hamamelidis. Journal of Chemical Ecology, 29(12), 2703-2720. http://dx.doi.org/10.1023/B:JOEC.0000008014.12309.04

Roberts, M. F., \& Wink, M. (1998). Alkaloids: Biochemistry, Ecology, and Medicinal Applications. Plenum Press New York. http://dx.doi.org/10.1007/978-1-4757-2905-4

Rhodes, M. J. (1994). Physiological roles for secondary metabolites in plants: some progress, many outstanding problems. Plant Molecular Biology 24(1), 1-20. http:// dx.doi.org/10.1007/BF00040570

Roitsch, T., \& González, M. C. (2004). Function and Regulation of Plant Invertases: Sweet Sensations Trends in Plant Science, 9, 606-613. http://dx.doi.org/10.1016/j.tplants.2004.10.009

Rossetti, S., \& Bonatti, P. M. (2001). In Situ Histochemical Monitoring of Ozone-and TMV- induced Reactive Oxygen Species in Tobacco Leaves. Plant Physiology and Biochemistry, 39, 433-442. http://dx.doi.org/10.1016/S0981-9428(01)01250-5

Róstas, M., Maag, D., Ikegami, M., \& Inbar, M. (2013). Gall Volatiles Defend Aphids Against a Browsing Mammal. BMC Evolutionay Biology, 13, 193-204. http://dx.doi.org/10.1186/1471-2148-13-193

Salnikov, V. V., Grimson, M. J., Seagull, R. W., Haigler, C. H. (2003). Localization of Sucrose Synthase and Callose in Freeze-Substituted Secondary-Wall-Stage Cotton Fibers. Protoplasma, 221, 175-184. http://dx.doi.org/10.1007/s00709-002-0079-7

Sass, J. E. (1951) Botanical microtechnique. Iowa State College Press, Ames. http://dx.doi.org/10.5962/bhl.title.5706

Schönrogge, K., Harper, L. J., \& Lichtenstein, C. P. (2000). The Protein Content of Tissues in Cynipid Galls (Hymenoptera: Cynipidae): Similarities Between Cynipid Galls and Seeds. Plant, Cell \& Environment, 23(2), 215-222. http://dx.doi.org/ 10.1046/j.1365-3040.2000.00543.x

Sturm, A., \& Tang, G. Q. (1999). The Sucrose-Cleaving Enzymes of Plants are Crucial for Development, Growth and Carbon Partitioning. Trends in Plant Science, 4(10), 401-407. http://dx.doi.org/ 10.1016/S1360-1385(99)01470-3

Vecchi, C., Menezes, N. L., Oliveira, D. C., Ferreira, B. G., \& Isaias, R. M. S. (2013). The Redifferentiation of Nutritive Cells in Galls Induced by Lepidoptera on Tibouchina pulchra (Cham) Cogn Reveals Predefined Patterns of Plant Development. Protoplasma, 250, 1363-1368. http://dx.doi.org/10.1007/s00709-013-0519-6

Wagner, H., Bladt, S., \& Zgainski, E. M. (1984). Plant Drug Analysis. Springer-Verlag, Berlin. http://dx.doi.org/10.1007/978-3-662-02398-3

Wind, J., Smeekens, S., Hanson, J. (2010) Sucrose: Metabolite and Signaling Molecule. Phytochemistry, 71, 1610-1614. http://dx.doi.org/10.1016/j.phytochem.2010.07.007

Wittich, P. E., Vreugdenhil, D. (1998). Localization of Sucrose Synthase Activity in Developmental Maize Kernels by in Situ Enzyme Histochemistry. Journal of Experimental Botany, 49(324), 1163-1171. http://dx.doi.org/10.1093/jxb/49.324.1163

Zrenner, R., Salanoubat, M., Willmitzer, L., \& Sonnewald, U. (1995). Evidence for the Crucial Role of Sucrose Synthase for Sink Strength Using Transgenic Potato Plants Solanum tuberosum L. Plant Journal, 7(1), 97-107. http://dx.doi.org/10.1046/j.1365-313X.1995.07010097.x

\section{Copyrights}

Copyright for this article is retained by the author(s), with first publication rights granted to the journal.

This is an open-access article distributed under the terms and conditions of the Creative Commons Attribution license (http://creativecommons.org/licenses/by/4.0/). 